\title{
Morphological and Electrical Characterization of SiNWs Synthesized by Electroless Metal Assisted Chemical Etching Method
}

\author{
Rabina Bhujel1,*, Sadhna Rai1, Utpal Deka², Joydeep Biswas ${ }^{3}$, Bibhu Prasad Swain ${ }^{4, \dagger}$ \\ ${ }^{1}$ Centre for Materials Science and Nanotechnology, Sikkim Manipal Institute of Technology, Sikkim Manipal \\ University, Majhitar, Rangpo-737136, East Sikkim, India \\ ${ }^{2}$ Department of Physics, Sikkim Manipal Institute of Technology, Sikkim Manipal University, Majhitar, \\ Rangpo-737136, East Sikkim, India \\ ${ }^{3}$ Department of Chemistry, Sikkim Manipal Institute of Technology, Sikkim Manipal University, Majhitar, \\ Rangpo-737136, East Sikkim, India \\ ${ }^{4}$ Department of Physics, National Institute of Technology, Manipur, Langol-795004, India
}

(Received 10 January 2021; revised manuscript received 25 March 2021; published online 09 April 2021)

\begin{abstract}
Silicon nanowires (SiNWs) were synthesized by following two-step electroless metal-assisted chemical etching method (EMACE) by taking silver as the metal catalyst. The effect of $\mathrm{AgNO}_{3}$ concentration on the growth of SiNWs was studied with the help of scanning electron microscopic (SEM) images of SiNWs. The confirmation of the Si material was done with the help of X-ray diffraction (XRD) and energy dispersive X-ray (EDS) spectrum of SiNWs. As studied the optimum concentration required for the growth of SiNWs was 20 and $25 \mathrm{mM}$ of $\mathrm{AgNO}_{3}$ solution. The $I-V$ characteristics curves for SiNWs show diode characteristics as expected with the formation of a rectifying junction. The current obtained in the reverse biased region is very low of the order of $10^{-7}$ for SiNWs synthesized by using $20 \mathrm{mM} \mathrm{AgNO}_{3}$ concentration as compared to the using $25 \mathrm{mM} \mathrm{AgNO}_{3}$ prepared SiNWS, which attributes its superiority in the application of ultra-small sized photodiodes with high sensitivity. Therefore, the current research work shows the variety of applications of SiNWs in electrics, optoelectronics as well as in sensors due to their very good electrical conductivity and their diode characteristics.
\end{abstract}

Keywords: SiNWs, EMACE, SEM, $I-V$ characteristics.

DOI: 10.21272/jnep.13(2).02003

PACS number: 81.16.Be

\section{INTRODUCTION}

$\mathrm{Si}$ is one of the most extensively studied semiconducting materials by researchers from across the globe due to its wide range of applications in solar cells, light-emitting diodes, transistors, sensors, etc. Si covers approximately $27.7 \%$ of the earth's crust; therefore, it is the second most abundant element in the earth. The bandgap of $\mathrm{Si}$ is $1.12 \mathrm{eV}$ and is indirect. As Si has an indirect bandgap, it prevents the interband radiative recombination. Therefore, silicon nanowires (SiNWs) the 1D counterpart of Si was introduced such that the movement of electrons is confined in particular directions and hence the electrical properties of the devices can be enhanced to many fold times. The properties of SiNWs are entirely different from their bulk counterpart due to the quantum confinement effect in SiNWs. SiNWs are one of the most promising candidates for their future applications in nanoelectronics and optoelectronic devices due to their extremely good electrical, optoelectronic, and mechanical properties [1-7].

Concerning the synthesis of SiNWs, various methods have been reported so far which are widely used. The different techniques for the synthesis of SiNWs are chemical vapor deposition (CVD) [8], evaporation [9], physical-chemical vapor deposition (PECVD) [10], vapor solid-liquid growth (VLS) [11], etc. The abovementioned techniques possess various drawbacks like high temperature, hazardous silicon precursors, expen- sive equipment, and other non-favorable conditions that limit their use in the synthesis process. Therefore, in this work, we chose the electroless metal-assisted chemical etching (EMACE) method for the synthesis of SiNWs [12]. This method has gained a lot of interest from the researchers because of its easy synthesis procedure and cost-effectiveness. Also, EMACE technique allows the tuning of various properties of SiNWs by easily varying the parameters of SiNWs as per the requirement for its application in a particular field. SiNWs synthesized by electroless etching method has large-scale ordering and has one dimensional structure. Because of their unique characteristics SiNWs have extremely good electrical properties and are also able to suppress the reflectivity below $5 \%$ over a wide spectral range of 300-1000 $\mathrm{nm}$. Finally, the nanosize of SiNWs also makes it an important material for its application in ultra small sized photodiodes [13-15]. Therefore, in this paper, we report the synthesis of SiNWs by EMACE method, the morphological and structural characterization of SiNWs by scanning electron microscopy (SEM), and the electrical characterization of SiNWs with different diameters.

\section{EXPERIMENTAL DETAILS}

At first, $n$-type Si wafers were cleaned by following the Radio Corporation of America (RCA) cleaning procedure. The cleaned Si wafers were then dipped in the

\footnotetext{
*bibhuprasad.swain@gmail.com

$\dagger$ rabina29@gmail.com

The results were presented at the International Conference on Multifunctional Nanomaterials (ICMN2020)
} 
solution containing an aqueous solution of $\mathrm{HF}$ and $\mathrm{Ag}$ $\mathrm{NO}_{3}$ for 1 min at room temperature. The concentration of $\mathrm{AgNO}_{3}$ was varied from 5-50 mM. The concentration of $\mathrm{HF}$ was fixed at $4.8 \mathrm{M}$. After that the silver nanoparticles coated Si substrates were immersed into an etching solution containing $\mathrm{HF}(4.8 \mathrm{M})$ and $\mathrm{H}_{2} \mathrm{O}_{2}(0.808 \mathrm{M})$ in dark at room temperature. The etching time was fixed to $5 \mathrm{~min}$. The etched Si wafer is finally put in concentrated nitric acid for $30 \mathrm{~min}$ to remove the silver nanoparticles.

The SEM characterization of the samples was done using JEOL JSM-5510, XRD was done using the Bruker D8 Advance and the $I-V$ characterization was performed using KEYSIGHT (B2901A) precession source/measure unit.

\section{RESULTS AND DISCUSSION}

Fig. 1 shows the SEM images of $n$-SiNWs synthesized by varying the $\mathrm{AgNO}_{3}$ concentration from 5$50 \mathrm{mM}$. It is clear from the images that, a very low and high concentration of $\mathrm{AgNO}_{3}$ i.e. $5 \mathrm{mM}$ and $50 \mathrm{mM}$ does not favor the formation of SiNWs. At a low concentration of $5 \mathrm{mM} \mathrm{AgNO}$, only pore-like structure has been formed which may be due to the deposition of extremely small-sized Ag NPs, while at very high concentration Ag NPs are agglomerated to form bigger sized clusters of $\mathrm{Ag}$ NPs which induces the etching of $\mathrm{Si}$ substrate in random fashion giving rise to randomly etched Si substrate. When the concentration of $\mathrm{AgNO}_{3}$ was slowly increased from 5 to $15 \mathrm{mM}$, we observed that in some of the portion SiNWs is grown properly while some still contained pore-like Si structure. The best result was obtained when the concentration of $\mathrm{AgNO}_{3}$ was taken as 20 and $25 \mathrm{mM}$ as observed from the SEM images shown in Fig. 1. It can be seen that the surface of $n$-Si is covered with densely packed vertically aligned arrays of SiNWs for both SiNWs synthesized by taking 20 and $25 \mathrm{mM} \mathrm{AgNO}_{3}$ concentration.

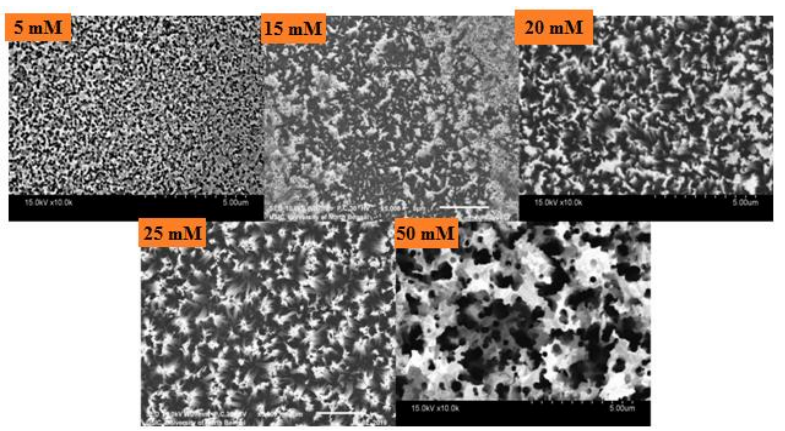

Fig. 1 - SEM images of Si nanostructures obtained by varying the $\mathrm{AgNO}_{3}$ concentration from 5 to $50 \mathrm{mM}$

Fig. 2 shows SEM characteristic images of SiNWs synthesized by taking 20 and $25 \mathrm{mM}$ of $\mathrm{AgNO}_{3}$ concentration and etched for $5 \mathrm{~min}$. SiNWs arrays are grown vertically on $\mathrm{Si}$ substrate having the diameter in the range of $40-90 \mathrm{~nm}$ for the SiNWs synthesized taking $20 \mathrm{mM} \mathrm{AgNO} 3$ solution and diameter in the range of 30-70 nm for $25 \mathrm{mM}$. The length of SiNWs was $\sim 2 \mu \mathrm{m}$ as the etching time was fixed for $5 \mathrm{~min}$. From the above result, one can conclude that $\mathrm{AgNO}_{3}$ concentration has a profound effect on the diameter of SiNWs. As men- tioned earlier a two-step, electroless etching method was used for the synthesis of SiNWs which completes in two steps. In the first step, silver nanoparticles were deposited on the Si substrate ( $n$-type) by following the redox reaction given below [16].

$$
\mathrm{Ag}^{+}+\mathrm{e}^{-} \rightarrow \mathrm{Ag}
$$

The Ag atoms then undergo nucleation to form $\mathrm{Ag}$ NPs. In the second step, etching of the Ag deposited $\mathrm{Si}$ substrate was done using a solution containing $\left(\mathrm{HF}+\mathrm{H}_{2} \mathrm{O}_{2}\right)$ in $1: 1$ ratio. The application of $\mathrm{HF}$ is to etch the $\mathrm{Si}$ wafer which is shown by the mechanisms given in the equations below:

$$
\begin{gathered}
\mathrm{Si}+2 \mathrm{H}_{2} \mathrm{O} \rightarrow \mathrm{SiO}_{2}+4 \mathrm{e}^{-}+4 \mathrm{H}^{+}, \\
\mathrm{SiO}_{2}+6 \mathrm{HF} \rightarrow\left[\mathrm{SiF}_{6}\right]^{2-}+2 \mathrm{H}_{2}+2 \mathrm{H}^{+} .
\end{gathered}
$$

The interface between the Ag NPs and SiNWs under it acts as the half cells where the redox reactions take place. From Eq. (1), it is clear that the size of Ag NPs has a great influence on the diameter of SiNWs. As the $\mathrm{Ag}$ NPs size increases, the diameter of SiNWs decreases which favors the obtained results as given above.

Fig. 3 represents the XRD spectrum of SiNWs. For SiNWs a sharp peak at $69.3^{\circ}$ is obtained with the corresponding plane of (400). The presence of sharp and intense peaks confirms that the crystalline structure of Si (JCPDS 27-1402) is also retained by SiNWs.

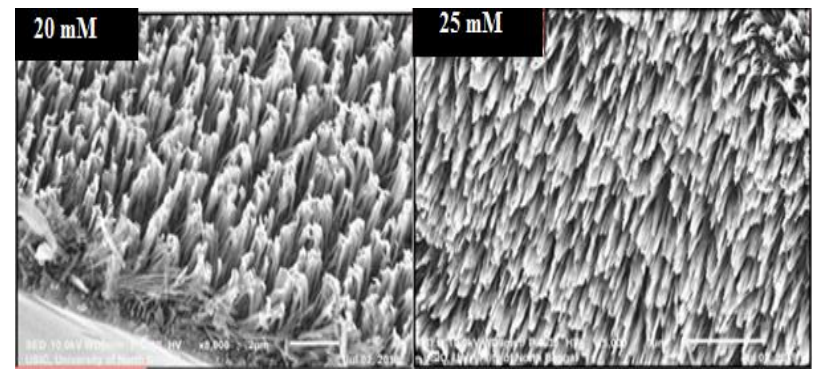

Fig. 2-SEM images of vertically aligned arrays of SiNWs with the $\mathrm{AgNO}_{3}$ concentrations of 20 and $25 \mathrm{mM}$

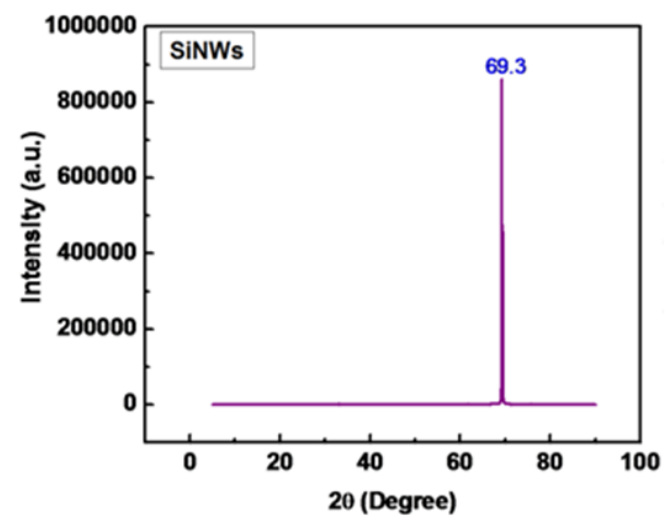

Fig. 3 - XRD spectra of SiNWs prepared by EMACE process

Fig. 4 shows the EDS analysis result for SiNWs. The result proves that the main element present is only $\mathrm{Si}$ and also traces of carbon due to environmental contamination. The percentage of Si obtained is 99.25 and carbon is just $0.75 \%$. This result proves that Ag NPs have been removed completely after the growth of SiNWs. 


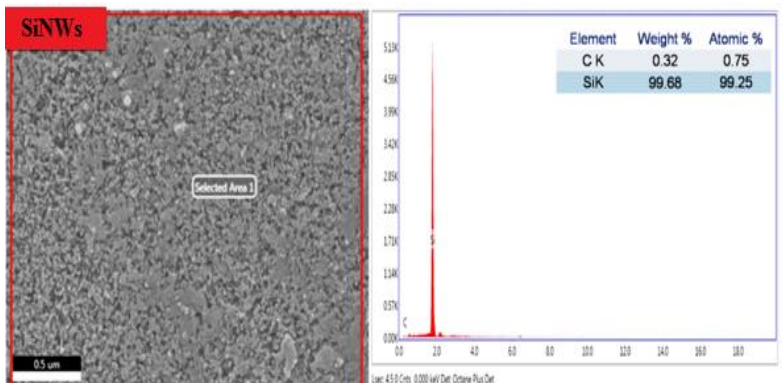

Fig. 4 - EDS spectra of SiNWs prepared by EMACE process

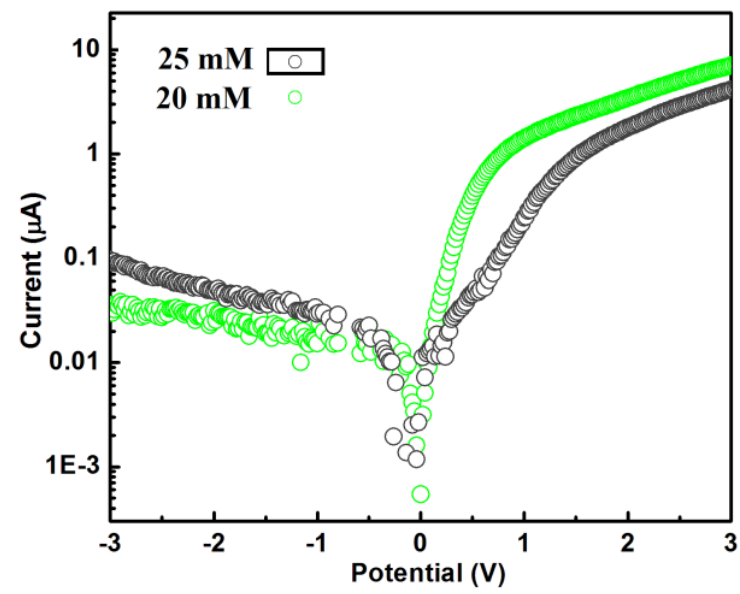

Fig. 4-I-V characteristic curves for SiNWs with different $\mathrm{AgNO}_{3}$ concentrations of 20 and $25 \mathrm{mM}$

Fig. 5 shows the $I-V$ characteristic curves of SiNWs with various diameters. From the $I$ - $V$ curve, one could see that SiNWs show diode characteristics with the occurrence of a rectifying junction. The rectifying characteristics of SiNWs/Si/Au are very good and the value of the rectifying ratio is in the order of 107.6, 52.9 for SiNWs with $20 \mathrm{mM} \mathrm{AgNO}_{3}$ concentration, and $25 \mathrm{mM}$ $\mathrm{AgNO}_{3}$ concentration respectively, obtained within the voltage range of -3 to $3 \mathrm{~V}$. Relevant papers are incorporated to support the results [17-19]. Moreover, the conduction mechanism in SiNWs/Si/Au heterojunction is favored by the space charge limited conduction mechanism. The ideality factor and current of the SiNWs/Au Schottky diode were calculated using the formula given below in Eq. (5):

\section{REFERENCES}

1. Y. Cui, C.M. Lieber, Science 291, 851 (2001).

2. B.S. Swain, B.P. Swain, S.S. Lee, N.M. Hwang, J. Phys. Chem. C 116 No 41, 22036 (2012).

3. B.S. Swain, S.S. Lee, S.H. Lee, B.P. Swain, N.M. Hwang, Chem. Phys. Lett. 494 No 4-6, 269 (2010).

4. B.S. Swain, B.P. Swain, N.M. Hwang, J. Appl. Phys. 108 No 7, 073709 (2010).

5. B.S. Swain, B.P. Swain, N.M. Hwang, J. Phys. Chem. C 114 No 36, 15274 (2010).

6. B.S. Swain, S.S. Lee, S.H. Lee, B.P. Swain, NM Hwang, J. Cryst. Growth 327 No 1, 276 (2011).

7. B.S. Swain, J.W. Park, S.M. Yang, K. Mahmood, B.P. Swain, J.G. Lee, N.M. Hwang, Appl. Phys. A 120 No 3, 889 (2015).

8. B.S. Swain, B.P. Swain, N.M. Hwang, Chem. Surf. Curr. Appl. Phys. 10, S439 (2010).

$$
\begin{gathered}
I=I_{0} \exp \left(\frac{q V}{\eta k T}\right), \\
\eta=\frac{q \Delta V}{k T \Delta \ln I},
\end{gathered}
$$

where $\eta$ is the ideality factor, $k$ is Boltzmann constant and $T$ is the absolute temperature. The value of the ideality factor is further calculated from the graph plotted between $\ln I$ and $V$. The ideality factor of SiNWs $(20 \mathrm{mM}) / \mathrm{Si} / \mathrm{Au}$ is 2.6 , while that of SiNWs $(25 \mathrm{mM}) /$ $\mathrm{Si} / \mathrm{Au}$ is 1.4. The existence of this $\eta>1$ is due to the presence of a large barrier in homogeneity between SiNWs, Si, and Au where the recombination of electron-hole pair takes place. The current obtained in the reverse biased region is very low of the order of $10^{-7}$ for SiNWs $(20 \mathrm{mM}) / \mathrm{Si} / \mathrm{Au}$ as compared to the SiNWs $(25 \mathrm{mM}) / \mathrm{Si} / \mathrm{Au}$, which attributes its superiority in the application of ultra-small sized photodiodes with high sensitivity [20].

\section{CONCLUSIONS}

SiNWs were synthesized by following two-step electroless metal-assisted chemical etching method. The concentration of $\mathrm{AgNO}_{3}$ was varied from 5-50 mM to study the effect of $\mathrm{AgNO}_{3}$ concentration on the growth of SiNWs. The presence of a peak at $69.3^{\circ}$ with the corresponding optimum concentration required for the growth of SiNWs is 20 and $25 \mathrm{mM}$ of $\mathrm{AgNO}_{3}$ solution. The plane of (400) in the XRD spectra of SiNWs gives the conformation for the presence of $\mathrm{Si}$. The $I-V$ SiNWs show diode characteristics. The current obtained in the reverse biased region is very low of the order with the occurrence of a rectifying junction of $10^{-7}$ for SiNWs synthesized by using $20 \mathrm{mM} \mathrm{AgNO}_{3}$ concentration as compared to the using $25 \mathrm{mM} \mathrm{AgNO} 3$ prepared SiNWs, which attributes its superiority in the application of ultra-small sized photodiodes with high sensitivity.

\section{ACKNOWLEDGEMENTS}

The authors acknowledge Dr. Ramdas Pai and Vasanthi Pai endowment fund for financially supporting to carry out of this entire work.

9. H. Pan, S. Lim, C. Poh, H. Sun, X. Wu, Y. Feng, Nanotech. 16, 417 (2005).

10. A. Colli, S. Hofmann, A. Fasoli, A.C. Ferrari, C. Ducati, R.E. Dunin-Borkowski, J. Robertson, Appl. Phys. A 85, 247 (2006).

11. R.S. Wagner, W.C. Ellis, Appl. Phys. Lett. 4, 89 (1964).

12. R. Bhujel, U. Rizal, A. Agarwal, B.S. Swain, B.P. Swain, JMEP 27, 2655 (2018).

13. D. Liu, Q. Chen, A. Chen, J. Wu, RSC Adv. 9, 23554 (2019).

14. Y. Sun, M. Yu, 4th IEEE International NanoElectronics Conference (2011).

15. J. Hu, L. Li, R. Wang, H. Chen, Y. Xu, Y. Zang, Z. Li, S. Feng, Q. Lei, C. Xia, J. H. Cho, Mater. Lett. 281, 128599 (2020).

16. R. Bhujel, S. Rai, U. Deka, J. Biswas, B.P. Swain, Mater. Today: Proceedings (2020). 
17. E. Saracino, L. Maiolo, D. Polese, M. Semprini, A. Isabel, B. Conejo, J. Gasparetto, S. Murtagh, M. Sola, L. Tomasi, F. Valle, L. Pazzini, F. Formaggio, M. Chiappalone, S. Hussain, M. Caprini, M. Muccini, L. Ambrosio, G. Fortunato, R. Zamboni, A. Convertino, V. Benfenati, Adv. Biosys. 4, 1900264 (2020).
18. M. Rahmani, S. Amdouni, M. Zaïbi, A. Meftah, Silicon 13, 179 (2021)

19. L.B. Ahmed, S. Naama, A. Keffous, A.H. Beya, T. Hadjersi, Prog. Nat. Sci.: Mater. Int. 25, 101 (2015).

20. Y. Sun, R.M. Yu, J. Salfi, C. Souza, H.E. Ruda, N. Singh, F. K.Lin, P. Lo, D.L. Kwong, Optics Express 19, 5464 (2011).

\title{
Морфологічні та електричні характеристики SiNWs, синтезованих методом безелектричного хімічного травлення за допомогою металів
}

\author{
Rabina Bhujel ${ }^{1}$, Sadhna Rai ${ }^{1}$, Utpal Deka ${ }^{2}$, Joydeep Biswas ${ }^{3}$, Bibhu Prasad Swain ${ }^{4}$
}

${ }^{1}$ Centre for Materials Science and Nanotechnology, Sikkim Manipal Institute of Technology, Sikkim Manipal University, Majhitar, Rangpo-737136, East Sikkim, India

${ }^{2}$ Department of Physics, Sikkim Manipal Institute of Technology, Sikkim Manipal University, Majhitar, Rangpo-737136, East Sikkim, India

${ }^{3}$ Department of Chemistry, Sikkim Manipal Institute of Technology, Sikkim Manipal University, Majhitar, Rangpo-737136, East Sikkim, India

${ }^{4}$ Department of Physics, National Institute of Technology, Manipur, Langol-795004, India

\begin{abstract}
Кремнієві нанодроти (SiNWs) синтезували, застосовуючи двоступеневий метод безелектричного хімічного травлення за допомогою металів (EMACE), беручи срібло як металевий каталізатор. Вплив концентрації $\mathrm{AgNO}_{3}$ на ріст SiNWs вивчали з використанням скануючих електронно-мікроскопічних зображень SiNWs. Підтвердження кремнієвого матеріалу було здійснено за допомогою рентгенівської дифракції (XRD) та енергодисперсійного рентгенівського (EDS) спектра SiNWs. Як було виявлено, оптимальна концентрація, необхідна для росту SiNWs, становила 20 і 25 мM розчину $\mathrm{AgNO}_{3}$. Як очікувалося, вольт-амперні характеристичні криві для SiNWs показують діодні характеристики з утворенням випрямляючого переходу. Струм, отриманий в області зворотного зміщення, е дуже низьким, порядку $10^{-7}$, для SiNWs, синтезованих з використанням $20 \mathrm{mM} \mathrm{AgNO}_{3}$ порівняно з використанням $25 \mathrm{mM}$ $\mathrm{AgNO}_{3}$, що пояснюе його перевагу в застосуванні фотодіодів надмалих розмірів з високою чутливістю. Тому дана дослідницька робота показуе різноманітність застосувань SiNWs в електротехніці, оптоелектроніщі, а також в датчиках завдяки дуже хорошій електропровідності та діодним характеристикам.
\end{abstract}

Ключові слова: SiNWs, EMACE, SEM, Вольт-амперні характеристики. 